\title{
PENGEMBANGAN LEMBAR KERJA PESERTA DIDIK (LKPD) BERWAWASAN GREEN CHEMISTRY UNTUK MENINGKATKAN KEMAMPUAN LITERASI SAINS PESERTA DIDIK PADA MATERI LARUTAN ELEKTROLIT DAN NON ELEKTROLIT
}

\section{DEVELOPMENT OF STUDENT WORKSHEET WITH GREEN CHEMISTRY INSIGHT TO INCREASE SCIENCE LITERACY ABILITY OF STUDENT IN MATTER OF ELECTROLYTE AND NON ELECTROLYTE SOLUTION}

\author{
Dymas Anisa dan *Mitarlis \\ Jurusan Kimia FMIPA Universitas Negeri Surabaya \\ e-mail: mitarlis@unesa.ac.id
}

\begin{abstract}
Abstrak
Penelitian ini bertujuan menghasilkan LKPD berwawasan green chemistry untuk meningkatkan kemampuan literasi sains peserta didik pada materi larutan elektrolit dan non elektrolit yang layak. Prinsip-prinsip green chemistry yang dikaji dalam penelitian ini terbatas pada prinsip green chemistry no 1, 7, dan 12. Metode penelitian pengembangan menggunakan model 4-P (pendefinisian, perancangan, pengembangan, dan penyebaran) dan dibatasi hanya sampai tahap pengembangan. Uji coba terbatas dilakukan kepada 12 peserta didik di kelas X IPA 6 SMA. Pengembangan LKPD dinyatakan layak apabila memenuhi tiga aspek, meliputi aspek validitas, kepraktisan, dan keefektifan. Dikatakan valid, praktis, dan efektif jika didapatkan hasil persentase $\geq 61 \%$. Hasil pengembangan LKPD disimpulkan bahwa kelayakan LKPD pada aspek validitas terdiri dari dua hal, yaitu validitas isi yang memperoleh persentase $79,75 \%$ yang berada pada kriteria valid dan validitas konstruk mendapatkan persentase $82,84 \%$ dengan kriteria sangat valid. Kepraktisan LKPD ditinjau dari observasi aktivitas dan angket respon peserta didik yang masing-masing memperoleh hasil praktis sekali dengan rata-rata persentase sebesar 93,05\% dan 94,79\%. Aspek keefekifan ditinjau dari hasil tes kemampuan literasi sains yang memperoleh nilai N-Gain sebanyak 0,84 yang berada di kategori tinggi, sehingga LKPD yang dikembangkan dinyatakan layak untuk digunakan dalam proses belajar mengajar.
\end{abstract}

Kata kunci: Lembar kerja peserta didik, Literasi Sains, dan Green Chemistry.

\begin{abstract}
The aims of the research to produce feasible student worksheet with green chemistry insight to increase science literacy ability of student in matter of electrolyte and non electrolyte solution. The green chemistry principles that studied in this research were limited to principle number 1, 7, and 12. This research method was used development research design of 4-P (define, design, develop, and desseminate) and only limited on develop stage. Limited test was conducted to 12 students in the class X IPA 6 SMA.. The results of the developed student worksheet concluded that the feasibility of student worksheet if it meets two aspects, namely validity, practicality, and effectiveness aspects. Said to be valid, practical, and effective if the percentage results are obtained $\geq 61 \%$. Feasibility student worksheet in the validity aspect consists of two things are content validity obtain percentage of 79,75\% which is in the valid criteria, and construct validity get percentage of $82,84 \%$ with very valid criteria. Practicality of student worksheet in terms from observation of student activities and student response questionnaire obtained very practical results with a percentage of 93,05\% and 94,79\%. Effectiveness aspect in terms from the results of improving science literacy ability indicated by $\mathrm{N}$-gain score of 0.84 which is in the high category, thus the developed of student worksheet is stated feasible for be used in teaching and learning process.
\end{abstract}

Key words: Student Worksheet, Science Literacy, and Green Chemistry.

\section{PENDAHULUAN}

Kimia mempunyai karakteristik yang sama dengan IPA dan merupakan bagian dari ilmu IPA. Karakteristik kimia merupakan bagian dari dua hal penting, yaitu kimia yang berperan sebagai proses (kerja ilmiah) dan produk, oleh karena itu perlu diterapkan dalam pembelajaran serta penilaian [1].
Perubahan global yang terjadi sangat berpengaruh pada kemajuan sistem pendidikan [2]. Pemerintah dalam memperbaiki mutu dan kualitas pendidikan, diwujudkan dengan adanya kurikulum 2013 revisi. Kurikulum 2013 pada pembelajaran kimia diharapkan dapat menghantarkan peserta didik untuk memenuhi kebutuhan Abad ke-21 [3]. 
Karakteristik ilmu kimia perlu diperhatikan dengan tujuan agar peserta didik dapat lebih mengkaji pengetahuan dan mendapatkan pemahaman yang bermakna dengan melakukan eksperimen serta dapat mengaplikasikannya dalam kehidupan sehari-hari, hal tersebut dibenarkan oleh Permendikbud No. 20 Tahun 2016 [4]. Peserta didik sedang membutuhkan bahan ajar untuk mempermudah dalam pencapaian setiap kompetensi, contohnya adalah LKPD.

Prastowo (2011) mendefinisikan LKPD sebagai kumpulan dari lembaran yang berisi materi berdasarkan kompetensi dasar, ringkasan, dan kegiatan yang dilakukan peserta didik [5]. Depdiknas (2008) menyatakan bahwa, paling tidak LKPD memuat judul, KD yang perlu dicapai, informasi secara singkat, langkah kerja serta tugas yang harus diselesaikan [6]. Lembar kerja peserta didik memuat fenomena di lingkungan sekitar melalui pendekatan literasi sains. Domain literasi sains seperti yang ditetapkan oleh PISA 2015 ada empat, yaitu domain pengetahuan, konteks, kompetensi, dan sikap [7]. Literasi sains diduga penting sebab dapat menjelaskan tentang fenomena berdasarkan pemahaman konsep yang dimiliki, serta dapat memecahkan masalah sehari-hari dengan menggunakan metode ilmiah [8].

Observasi yang dilaksanakan di SMA Negeri 14 Surabaya menyatakan sebanyak 62,5\% peserta didik tidak mengetahui penerapan nyata dari materi kimia, dan sebanyak $75 \%$ peserta didik mengatakan bahwa dalam pembelajaran kimia tidak sering menerapkan literasi sains. Observasi lapangan yang dilakukan dapat mengetahui bahwa pembelajaran menjadi kurang bermakna yang berpengaruh terhadap hasil belajar peserta didik [9]. Peserta didik yang mempunyai kemampuan literasi sains secara baik menyebabkan kebermaknaan dari pembelajaran sains [10].

Literasi sains dapat dilakukan pembelajaran melalui praktikum. Kemampuan peserta didik dapat ditingkatkan secara ilmiah dan kritis dalam menemukan konsep sendiri maupun mengaitkan konsep yang telah diperoleh dengan hasil percobaan [11]. Kegiatan laboratorium membuat lingkungan menjadi terganggu yang disebabkan oleh kurang ramahnya bahan kimia yang digunakan dan limbah hasil praktikum, hal ini dapat diminimalisir dengan menerapkan prinsipprinsip dari green chemistry [12]. Manahan (2006) mengemukakan bahwa, green chemistry merupakan rancangan dari produk bahan kimia dan proses pembuatannya yang dapat mengeliminasi bahan-bahan kimia yang bersifat racun dan berbahaya [13].

Abad ke-21 yang disebut sebagai masa modern ini, antara lain ditandai dengan meningkatnya secara pesat populasi dan penipisan sumber daya. Sumber daya alam digunakan terus menerus sehingga muncul masalah lingkungan yang semakin kompleks [12]. Peserta didik sebanyak $93,75 \%$ berdasarkan hasil prapenelitian tidak pernah mendengar/mengenal tentang green chemistry, padahal penguasaan literasi sains terutama pada lingkungan dapat ditingkatkan dengan diterapkannya prinsip-prinsip green chemistry [14].

Salah satu materi yang pembelajarannya harus dilakukan praktikum dan menekankan pada fenomena sehari-hari adalah materi larutan elektrolit dan non elektrolit. Karakteristik yang dimiliki dari materi tersebut yaitu sifatnya yang abstrak, dimana menuntut peserta didik dapat merancang dan melakukan percobaan pada saat menguji satu per satu larutan untuk penemuan konsep serta membutuhkan kejelian dalam mengambil kesimpulan berdasarkan data hasil percobaan [15].

Bahan ajar yang disajikan khususnya materi larutan elektrolit dan non elektrolit selama ini belum tepat penggunaannya terhadap pemanfaatan yang ada dalam kehidupan [16]. Aplikasi dari materi ini menyajikan contoh yang masih umum yaitu alat uji daya hantar listrik dengan menggunakan baterai (tidak ramah lingkungan), sehingga peserta didik perlu dikenalkan inovasi baru yaitu menggunakan buahbuahan sebagai penggantinya.

Penelitian perlu dilakukan berdasarkan pemaparan di atas, yang bertujuan menghasilkan LKPD berwawasan green chemistry untuk meningkatkan kemampuan literasi sains pada materi larutan elektrolit dan non elektrolit. 


\section{METODE}

Penelitian pengembangan ini mengikuti rancangan model 4-P yang dikembangkan oleh Ibrahim \& Wahyusukartiningsih yang terdiri dari 4 tahap tetapi dibatasi hingga tahap pengembangan [17]. Uji coba terbatas yang dilaksanakan dengan menggunakan peserta didik sebanyak 12 dari kelas X IPA 6 di SMA Negeri 14 Surabaya. Tahapan model pengembangan 4-P diuraikan sebagai berikut:

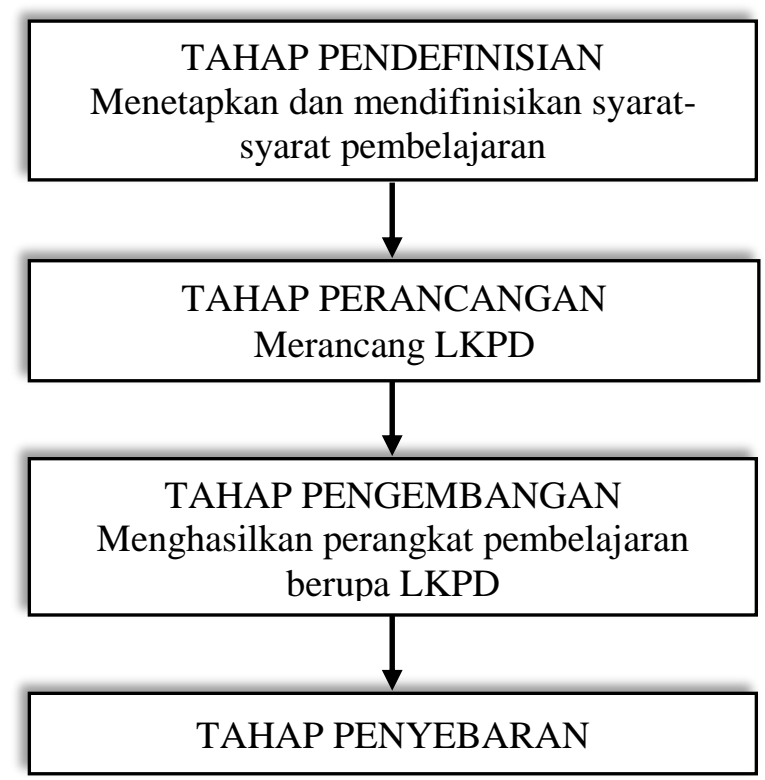

Gambar 1. Tahapan Model Pengembangan 4-P

Lembar kerja peserta didik yang dikembangkan dapat dikatakan layak apabila memenuhi 3 aspek yaitu aspek validitas, kepraktisan serta keefektifan. Proses validasi dari LKPD dilakukan oleh dua dosen kimia UNESA serta satu guru kimia SMA Negeri 14 Surabaya dengan memberikan instrumen lembar validasi. Data hasil validasi LKPD dianalisis dengan menggunakan perhitungan pada skala Likert yang ditunjukkan pada Tabel berikut:

Tabel 1. Skala Likert

\begin{tabular}{cc}
\hline Penilaian & Nilai Skala \\
\hline 1 & Tidak Baik Sekali \\
2 & Kurang Baik \\
3 & Cukup Baik \\
4 & Baik \\
5 & Baik Sekali
\end{tabular}

[18]

Data hasil perhitungan tersebut dihitung persentasenya dengan rumus berikut:
Persentase (\%) $=\frac{\sum \text { skor hasil dari data }}{\text { nilai kriteria }} \times 100 \%$ Interpretasi data ditunjukkan dalam Tabel 2.

Tabel 2. Kriteria Interpretasi Skor Validitas

\begin{tabular}{cc}
\hline Persentase (\%) & Kriteria \\
\hline $0-20$ & Tidak Valid \\
$21-40$ & Kurang Valid \\
$41-60$ & Cukup Valid \\
$61-80$ & Valid \\
$81-100$ & Sangat Valid \\
\hline
\end{tabular}

[18]

Lembar kerja peserta didik yang dikembangkan dinyatakan valid berdasarkan dari kriteria interpretasi skor validitas, bilamana hasil persentase terpenuhi $\geq 61 \%$.

Kelayakan LKPD pada aspek kepraktisan dilihat berdasarkan observasi aktivitas dan angket respon peserta didik. Obervasi dilakukan oleh observer dengan mengamati tiap aspek yang dilakukan oleh masing-masing individu pada tiap kelompok. Data dari hasil observasi aktivitas tersebut dianalisis dengan menggunakan skala Guttman yang terdapat dalam Tabel 3.

Tabel 3. Kriteria Skala Guttman

\begin{tabular}{cc}
\hline Jawaban & Skor \\
\hline Tidak & 0 \\
Ya & 1 \\
\hline
\end{tabular}

Lembar angket respon peserta didik disertai pilihan jawaban berupa "Ya" dan "Tidak". Peserta didik memberikan tanggapan pada lembar angket ini setelah menggunakan LKPD yang dikembangkan. Data hasil angket dikaji dengan skala Guttman yang terdapat di Tabel 4.

Tabel 4. Kriteria Skala Guttman

\begin{tabular}{ccc}
\hline Jawaban & $\begin{array}{c}\text { Skor } \\
\text { Pertanyaan } \\
\text { Negatif }\end{array}$ & $\begin{array}{c}\text { Skor } \\
\text { Pertanyaan } \\
\text { Positif }\end{array}$ \\
\hline Ya & 0 & 1 \\
Tidak & 1 & 0 \\
\hline
\end{tabular}

Hasil perhitungan berdasarkan kriteria skala Guttman diubah ke dalam bentuk persentase dengan rumus:

$$
P=\frac{F}{N} \times 100 \%
$$


Keterangan:

$\mathrm{P}=$ persentase dari jawaban

$\mathrm{F}=$ jumlah yang menjawab "Ya" untuk pertanyaan bersifat positif atau jumlah jawaban "Tidak" untuk pertanyaan bersifat negatif

$\mathrm{N}=$ jumlah responden

Persentase aktivitas dan respon peserta didik diinterpretasikan ke dalam Tabel 5.

Tabel 5. Kriteria Interpretasi Skor Aktivitas dan Respon Peserta Didik

\begin{tabular}{cc}
\hline Persentase (\%) & Kriteria \\
\hline $0-20$ & Tidak Praktis Sekali \\
$21-40$ & Kurang Praktis \\
$41-60$ & Cukup Praktis \\
$61-80$ & Praktis \\
$81-100$ & Praktis Sekali \\
\hline
\end{tabular}

[18]

Lembar kerja peserta didik dikatakan praktis berdasarkan dari kriteria interpretasi di atas, jika persentase yang didapatkan $\geq 61 \%$.

Kelayakan LKPD terhadap aspek keefektifan dilihat dari nilai tes kemampuan literasi sains. Pretest dilaksanakan pada awal pembelajaran, sedangkan posttest di akhir pembelajaran setelah menggunakan LKPD yang dikembangkan. Data hasil tes dapat dihitung menggunakan rumus:

Skor $=\frac{\text { jumlah skor yang didapatkan }}{\text { jumlah skor maksimal }} \times 100 \%$

Uji normalitas dilakukan dengan menggunakan SPSS metode Kolmogrof, jika didapatkan $\alpha>0,5$ maka dinyatakan berdistribusi normal. Peningkatan data hasil pretest dan posttest selanjutnya dianalisis dengan perhitungan N-Gain menggunakan rumus [19]:

$$
\langle\mathrm{g}\rangle=\frac{\text { Sposttest-Spretest }}{\text { Smax-Spretest }}
$$

Keterangan:

$\langle\mathrm{g}\rangle \quad=$ Gain (besar peningkatan)

$\mathrm{S}_{\text {pretest }}=$ Skor pretest

$\mathrm{S}_{\text {posttest }}=$ Skor posttest

$\mathrm{S}_{\max }=$ Skor maksimum

Besarnya hasil peningkatan yang didapatkan peserta didik selanjutnya diinterpretasikan ke dalam Tabel 6.
Tabel 6. Kategori Pengelompokkan Nilai N-Gain

\begin{tabular}{cc}
\hline Nilai & Kategori \\
\hline $\mathrm{g}>0,7$ & Tinggi \\
$0,7 \geq \mathrm{g} \geq 0,3$ & Sedang \\
$\mathrm{g}<0,3$ & Rendah \\
\hline
\end{tabular}

Lembar kerja peserta didik dikatakan efektif dan layak digunakan berdasarkan kategori di atas, apabila hasil peningkatan tes kemampuan literasi sains mendapatkan nilai $\geq 0,3$ yang berada dalam kategori sedang.

\section{HASIL DAN PEMBAHASAN}

Bagian ini akan dijabarkan hasil beserta pembahasan tentang penelitian pengembangan LKPD berwawasan green chemistry untuk meningkatkan kemampuan literasi sains pada materi larutan elektrolit dan non elektrolit. Lembar kerja peserta didik dikatakan layak apabila tiga aspek terpenuhi, yaitu aspek validitas, kepraktisan, dan keefektifan. Metode penelitian merujuk pada model pengembangan 4-P menurut Ibrahim \& Wahyusukartingsih yang dibatasi sampai tahap pengembangan, berikut tahapan-tahapannya:

\section{Tahap Pendefinisian}

Tahapan awal merupakan tahap pendefinisian yang mempunyai tujuan untuk menetapkan beserta mendefnisikan ketentuan dari pembelajaran. Lima langkah yang perlu dilakukan yaitu: analisis dari standar isi, peserta didik, tugas, konsep, dan perumusan tujuan pembelajaran.

Beberapa hal yang harus dipertimbangkan pada analisis standar isi yaitu: (1) kurikulum yang masih berlaku yaitu kurikulum 2013 revisi; (2) teori belajar yang relevan, misalnya teori belajar bermakna Ausubel. Teori tersebut relevan dengan prinsip pembelajaran K-13 revisi yang menjadikan peserta didik melakukan pencarian secara mandiri; dan (3) tuntutan masa depan seperti kebutuhan abad ke-21. Perilaku tuntutan masa depan yang dapat dilakukan salah satunya dengan menerapkan prinsip green chemistry, dikarenakan salah satu masalah yang krusial pada Abad ke-21 yaitu masalah lingkungan.

Analisis peserta didik yang dilaksanakan agar dapat mengetahui gambaran karakteristik dari 
pengguna LKPD diantaranya: kemampuan akademik, usia atau tingkat kedewasaan, pengalaman belajar sebelumnya, dan keterampilan yang dimiliki sebelumnya. Rentang usia peserta didik kelas $\mathrm{X}$ adalah 14-16 tahun, dimana umur tersebut menurut teori perkembangan kognitif Piaget berada di tahap operasional formal. Kemampuan yang dimiliki peserta didik pada tahap tersebut yaitu dapat berpikir secara abstrak, menganalisis, dan menyelesaikan masalah dengan metode ilmiah [20].

Analisis tugas dilakukan bertujuan untuk mencapai kompetensi dengan menentukan keterampilan yang akan dikuasai oleh peserta didik. Analisis ini perlu memperhatikan kesesuaian isi pada LKPD dengan KI, KD, dan IPK yang sesuai dengan $\mathrm{K}-13$ revisi.

Analisis konsep dilaksanakan untuk mengidentifikasi, merinci konsep-konsep utama yang relevan serta menyusunnya secara terstruktur. Materi larutan elektrolit dan non elektrolit merupakan konsep pokok yang akan diajarkan dengan mengacu pada KD 3.8 yaitu menganalisis sifat larutan berdasarkan daya hantar listriknya dan 4.8 yaitu membedakan daya hantar listrik berbagai larutan melalui perancangan dan pelaksanaan percobaan.

Perumusan tujuan pembelajaran dilakukan untuk menentukan tujuan dari pembelajaran yang akan dicapai oleh peserta didik. Rumusan dari tujuan harus menggunakan kata kerja operasioanl (KKO) yang mengandung komponen audience, behaviour, bila memungkinkan dilengkapi dengan condition, serta degree.

\section{Tahap Perancangan}

Tahapan kedua merupakan tahap perancangan yang dilakukan untuk merancang perangkat pembelajaran didasarkan pada hasil analisis tahap pendefinisian. Ada empat tahapan antara lain: penyusunan standar tes, pemilihan media, pemilihan format, dan membuat rancangan awal. Penyusuan standar tes yang merupakan tes kemampuan literasi sains berupa soal essay yang disesuaikan dengan karakteristik soal PISA, tujuan dari pembelajaran, dan kemampuan kognitif peserta didik. Pengadaan tes dapat meninjau kelayakan LKPD khususnya aspek keefektifan.

Media pembelajaran yang dipilih disesuaikan dengan materi serta tujuan dari pembelajaran, hal tersebut berguna agar peserta didik mencapai kompetensi dasar yang diharapkan. Pemilihan media cetak berupa LKPD diharapkan dapat memberikan pembelajaran bermakna serta memudahkan peserta didik dalam memahami materi kimia dan menerapkan prinsip green chemistry.

Pemilihan format yang dapat menarik minat peserta didik, memudahkan dan membantu dalam proses pembelajaran. Pemilihan format untuk menyusun LKPD dapat mengacu pada Depdiknas (2008) mengenai struktur penyusunan LKPD [6].

Tahap terakhir yaitu membuat rancangan awal dari perangkat pembelajaran yaitu LKPD sebagai draf I. LKPD yang dikembangkan memiliki tiga bagian utama antara lain: pendahuluan, isi, dan penutup.

\section{Tahap Pengembangan}

Tahap pengembangan yaitu tahapan ketiga yang akan dihasilkan perangkat pembelajaran berupa LKPD. Tahap pengembangan ini menghasilkan LKPD berwawasan green chemistry yang kemudian dilakukan proses telaah dan revisi, proses validasi oleh para ahli diikuti revisi, sehingga LKPD yang dihasilkan sebagai draf III valid dan dapat digunakan untuk uji coba terbatas.

Rancangan awal LKPD sebagai draf I pada tahap telaah dan revisi dilakukan proses telaah oleh satu dosen kimia UNESA yaitu dosen pembimbing dengan menggunakan instrumen lembar telaah. Penelaah memberikan komentar dan saran guna perbaikan LKPD yang dikembangkan agar LKPD lebih tepat, efektif, dan dapat digunakan. Hasil telaah digunakan untuk revisi dan dihasilkan LKPD sebagai draf II.

Steffen-Peter Ballstead (dalam Depdiknas, 2008) mengungkapkan bahwa aktivitas seperti mencatat hasil pengamatan yang dapat memotivasi peserta didik merupakan bagian dari bahan ajar yang baik. Pernyataan tersebut telah disesuaikan dengan isi dalam LKPD, dimana peserta didik akan 
mencatat hasil pengamatan setelah melakukan percobaan. Depdiknas (2008) menyatakan bahwa, penyusunan bahan ajar cetak perlu memperhatikan aspek-aspek meliputi: (1) susunan tampilan; (2) bahasa yang mudah, menyangkut kalimat hubungan kalimat yang jelas; (3) stimulan, salah satunya enak tidaknya bahan ajar tersebut dilihat; dan (4) kemudahan dibaca [6].

Domain-domain literasi sains yang termuat dalam LKPD ditampilkan pada gambar berikut:

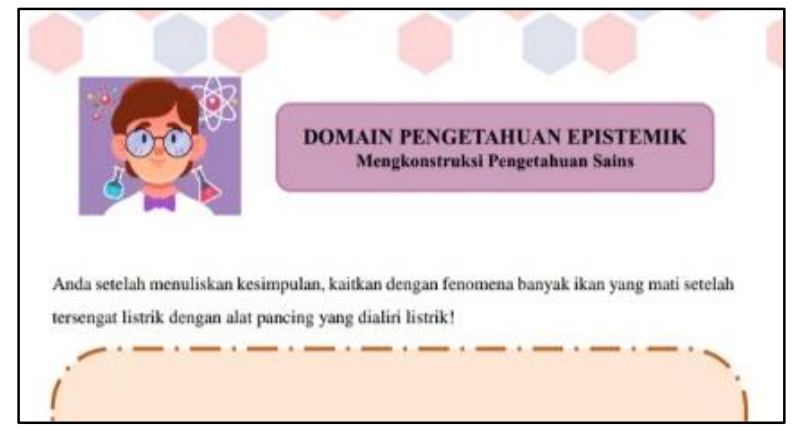

Gambar 2. Tampilan dari Domain Pengetahuan Epistemik dalam LKPD

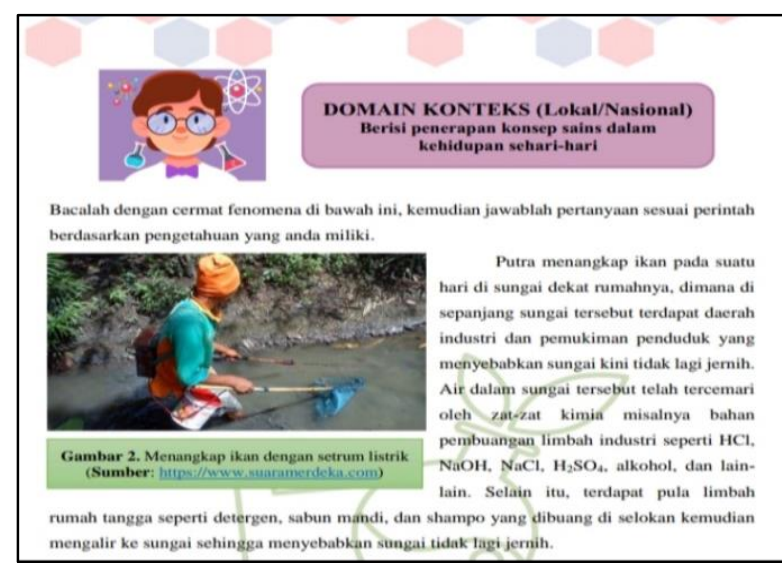

Gambar 3. Tampilan Domain Konteks pada LKPD

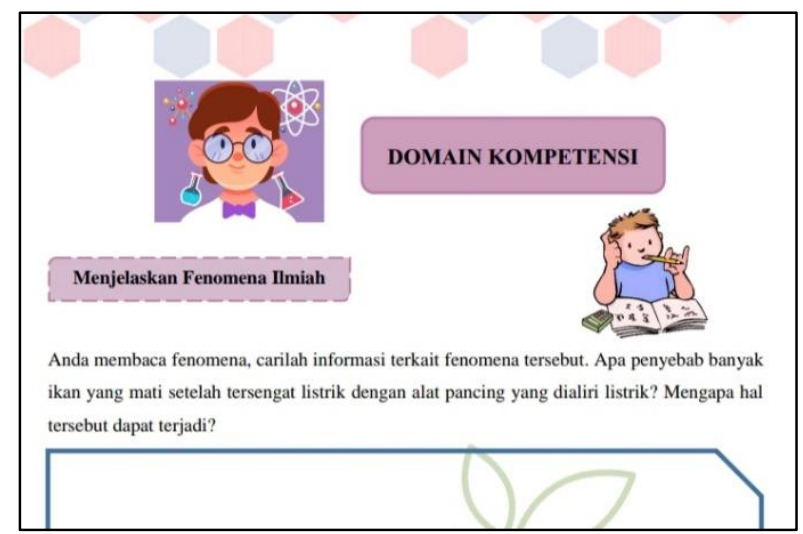

Gambar 4. Tampilan Domain Kompetensi pada LKPD

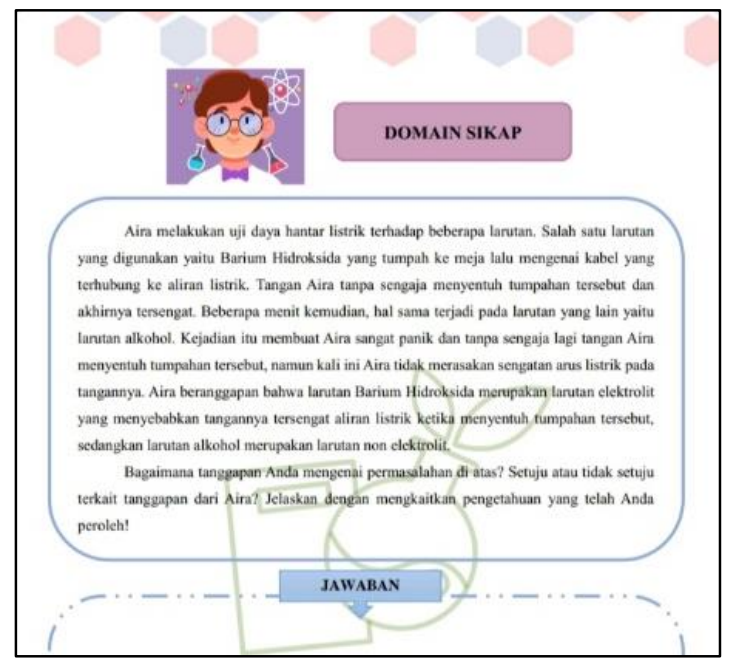

Gambar 5. Tampilan Domain Sikap pada LKPD

\section{Validitas LKPD}

Tahap awal pengembangan yang bertujuan untuk mengetahui validitas dari LKPD. Validator memberikan penilaian tidak hanya berupa skor saja, tetapi juga beberapa masukan dan saran terhadap LKPD. Revisi tahap kedua dilakukan yang kemudian dihasilkan LKPD sebagai draf III.

Lembar kerja peserta didik yang dikembangkan ditinjau berdasarkan kriteria validitas dari Plomp \& Nieveen (2010), menyatakan bahwa kriteria suatu produk dilihat dari validitas isi (content validity) serta validitas konstruk (construct validity) [21]. Data hasil validasi LKPD ditunjukkan pada Gambar 6 berikut ini:

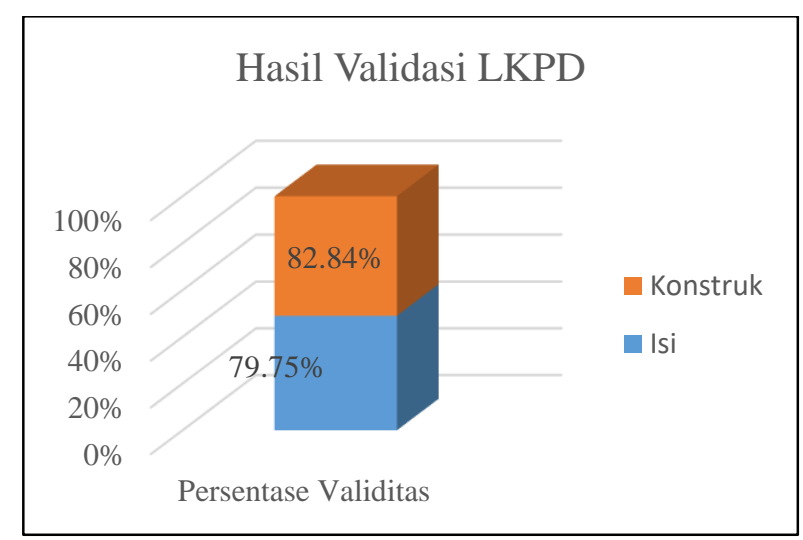

Gambar 6. Diagram Hasil Validasi LKPD

Validitas isi LKPD ditinjau dari beberapa aspek meliputi: kesesuaian materi dengan KD yang terdapat pada kurikulum 2013, kesesuaian dengan domain literasi sains dan prinsip-prinsip green chemistry, serta kebenaran substansi dari materi 
pembelajaran. Hasil validasi LKPD berdasarkan validitas isi mendapatkan rata-rata persentase sebesar 79,75\% dengan kriteria valid.

Komponen fenomena pada domain konteks di LKPD yang disajikan telah sesuai dengan pokok bahasan pada validitas isi, diharapkan peserta didik dapat menghubungkan fenomena baru dengan konsep yang ada ke dalam struktur kognitifnya sehingga pembelajaran menjadi bermakna [22]. Komponen tersebut relevan dengan teori belajar bermakna Ausubel.

Komponen kesesuaian LKPD dengan domain literasi sains didukung oleh teori belajar konstruktivisme Piaget, terutama pada domain pengetahuan prosedural dan pengetahuan epistemik. Peserta didik dapat membangun pengetahuannya sendiri melalui pengalaman baru berdasarkan pengetahuan yang sudah dimilikinya, sehingga dapat memecahkan masalah dengan ideide [23]. Domain kompetensi menafsirkan data dan bukti ilmiah pada LKPD, didukung oleh teori belajar penemuan Bruner bahwa peserta didik hendaknya belajar melalui percobaan sehingga dapat menemukan konsep dan prinsip baru [22].

Validitas konstruk LKPD ditinjau dari beberapa aspek meliputi: kriteria penyajian, kebahasaan, dan kegrafisan. Hasil dari validitas konstruk mendapatkan rata-rata persentase sebesar $82,84 \%$ berada pada kriteria sangat valid. Data hasil validitas konstruk dapat ditampilkan pada Gambar 7 berikut ini:

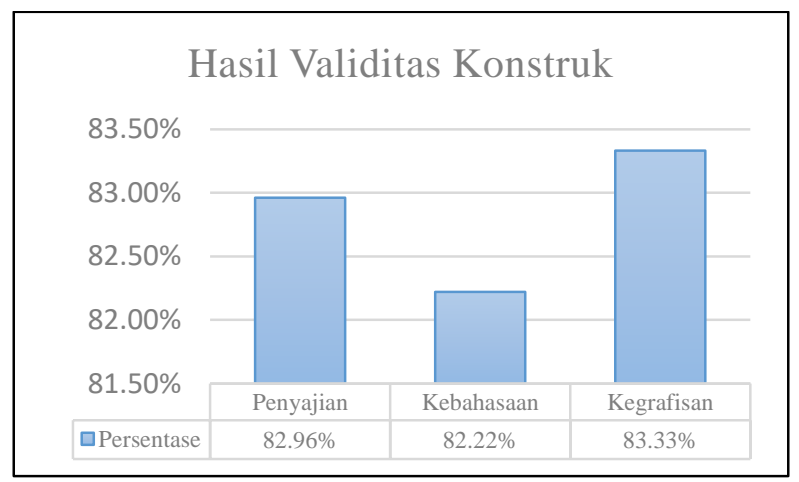

Gambar 7. Diagram Hasil Validitas Konstruk

Penelitian yang dilakukan oleh Riyadhin dan Mitarlis memperoleh hasil dari kriteria isi, kegrafikan, dan penyajian yang mendapatkan persentase $78,51 \%, \quad 82,2 \%$ dan $83,34 \%$ menunjukkan bahwa, LKS untuk melatihkan kemampuan literasi sains layak digunakan [8]. Lembar kerja peserta didik yang sudah dikatakan layak untuk digunakan dalam pembelajaran, kemudian uji coba terbatas dilaksanakan untuk mengetahui kepraktisan beserta keefektifan dari LKPD.

\section{Kepraktisan LKPD}

Plomp \& Nieveen (2010) mengemukakan bahwa kriteria kepraktisan ditinjau berdasarkan mudah tidaknya produk digunakan dan dipahami oleh pengguna [21]. Kepraktisan LKPD dilihat dari hasil observasi aktivitas dan angket respon peserta didik. Lembar observasi aktivitas berisikan aspekaspek aktivitas peserta didik, dimana setiap aspek aktivitas sudah disesuaikan dengan LKPD yang dikembangkan. Data hasil observasi aktivitas yang diperoleh, ditunjukkan dalam Tabel 7.

Tabel 7. Hasil Observasi Aktivitas Peserta Didik

\begin{tabular}{ccc}
\hline $\begin{array}{c}\text { Pertemuan } \\
\text { ke- }\end{array}$ & Persentase $(\%)$ & Kriteria \\
\hline 1 & 91,67 & Praktis Sekali \\
2 & 94,44 & Praktis Sekali \\
Rata-rata & 93,05 & Praktis Sekali \\
\hline
\end{tabular}

Pertemuan 1 ke pertemuan 2 berdasarkan dari hasil tersebut terjadi peningkatan. Aktivitas dari peserta didik memperoleh persentase sebesar 93,05\% berada pada kriteria praktis sekali.

Aktivitas penyelidikan ilmiah yang dimulai dari menyiapkan alat dan bahan, merancang prosedur percobaan hingga melakukan percobaan dapat membantu peserta didik untuk memecahkan persoalan yang terjadi di kehidupan sehari-hari. Kegiatan penyelidikan ilmiah tersebut relevan dengan teori konstruktivisme Piaget, dimana peserta didik dapat membangun pemahamannya sendiri yang berasal dari pengalaman baru berdasarkan pengetahuan yang dimilikinya sehingga dapat memecahkan masalah dengan ide-ide.

Peserta didik telah menerapkan prinsip green chemistry nomor 1 selama melakukan percobaan yaitu mencegah atau mengurangi limbah, seperti meminimalkan penggunaan bahanbahan kimia. Prinsip green chemistry nomor 7 yaitu menggunakan bahan baku yang bisa diperbarui, seperti buah-buahan yang digunakan 
sebagai pengganti baterai saat uji daya hantar listrik beberapa larutan. Prinsip green chemistry nomor 12 ialah meminimalkan potensi terjadinya kecelakaan, seperti menggunakan bahan-bahan kimia dengan konsentrasi rendah 1M. Green chemistry yang diterapkan dapat meningkatkan kemampuan literasi sains dengan memecahkan masalah di kehidupan sehari-hari, karena seperti yang diketahui penyebab utama masalah lingkungan adalah aplikasi dari sains [24].

Lembar angket respon dibagikan kepada 12 peserta didik dengan tujuan memberikan beberapa tanggapan setelah menggunakan LKPD yang dikembangkan. Lembar angket respon tersebut berisikan 16 pertanyaan berupa pertanyaan bersifat positif dan bersifat negatif, hal tersebut berguna untuk menghindari peserta didik yang mengisi angket dengan tidak sungguh-sungguh.

Lembar kerja peserta didik yang dikembangkan berdasarkan hasil angket respon, dapat membantu peserta didik mengetahui penerapan nyata pada materi larutan elektrolit dan non elektrolit yang mengakibatkan pembelajaran menjadi bermakna. Materi yang diterapkan berupa fenomena yang berada dalam domain konteks pada LKPD, seperti sumber listrik yang berasal dari buah belimbing. Respon peserta didik mengenai kegiatan percobaan menunjukkan bahwa melalui LKPD, dapat memecahkan masalah yang terjadi di sekitar, misalnya buah-buahan yang digunakan sebagai pengganti baterai.

$\begin{array}{lrrr}\text { Uraian dari } & \text { lembar } & \text { observasi } & \text { aktivitas } \\ \text { beserta angket } & \text { respon } & \text { peserta } & \text { didik } \\ \text { mengungkapkan } & \text { bahwa, } & \text { LKPD } & \text { yang }\end{array}$ dikembangkan dinyatakan efektif dan layak dipergunakan. Masing-masing memperoleh persentase sebesar $93,05 \%$ dan $94,79 \%$ yang berada pada kriteria praktis sekali. Penelitian Hidayatin \& Mitarlis memperoleh rata-rata persentase dari aktivitas yang dilaksanakan peserta didik sebesar $95 \%$ dengan interpretasi sangat praktis sehingga LKPD untuk melatihkan literasi sains pada materi koloid layak bila digunakan [3].

\section{Keefektifan LKPD}

Keefektifan LKPD diukur berdasarkan nilai tes kemampuan literasi sains. Pretest dilaksanakan untuk mengetahui pengetahuan awal sebelum menggunakan LKPD. Posttest dilakukan agar mengetahui pengetahuan akhir peserta didik setelah menggunakan LKPD yang dikembangkan.

Tes kemampuan literasi sains disesuikan dengan karakteristik soal PISA yang berupa soal essay. Nilai pretest beserta posttest disajikan pada Gambar 8 berikut ini:

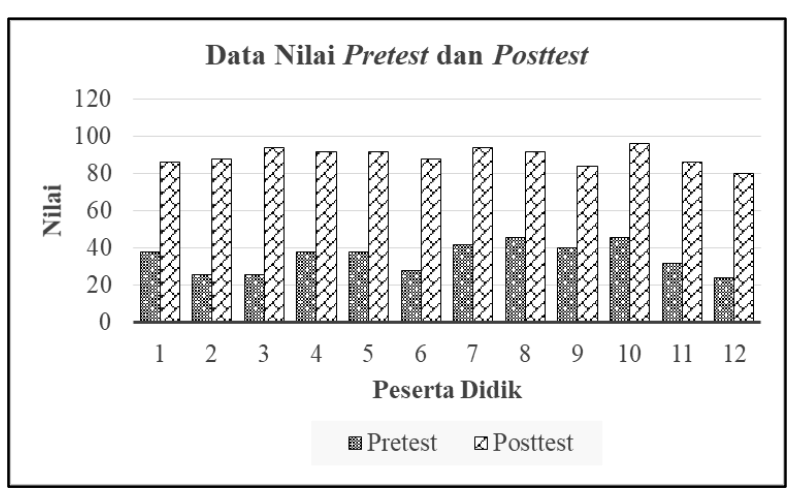

Gambar 8. Diagram Nilai Pretest dan Posttest

Diagram di atas menunjukkan bahwa hasil pretest dan posttest mengalami peningkatan. Semua peserta didik mendapatkan nilai pretest di bawah nilai KKM, hal tersebut disebabkan karena peserta didik belum ditingkatkan kemampuan literasi sainsnya dengan memperoleh soal-soal yang disertai domain-domain literasi sains dan wawasan green chemistry. Peserta didik juga belum terbiasa membentuk pengetahuannya sendiri antara konsep yang telah dimilikinya dengan pengalaman baru [2].

Uji normalitas yang telah dilakukan menyatakan nilai pretest beserta posttest berdistribusi normal, selanjutnya dianalisis dengan perhitungan N-Gain yang memiliki tujuan untuk mengetahui seberapa besar peningkatan kemampuan literasi sains dari peserta didik setelah penggunaan LKPD yang dikembangkan. Hasil tes yang didapatkan menyatakan bahwa seluruh peserta didik telah mengalami peningkatan kemampuan literasi sains setelah penggunaan LKPD yang dikembangkan.

Lembar kerja peserta didik berwawasan green chemistry berdasarkan pernyataan tersebut, dinyatakan efektif dengan nilai dari N-Gain 0,84 yang berada pada kategori tinggi. Wardani \& Mitarlis dalam penelitiannya mengalami peningkatan pada hasil tes literasi sains dengan 
perolehan nilai $\mathrm{N}$-Gain 0,78 (tinggi) sehingga LKPD pada materi hidrokarbon dan minyak bumi untuk meningkatkan keterampilan literasi sains layak digunakan [10].

Kemampuan literasi sains yang dimiliki peserta didik mengalami peningkatan signifikan sehingga menyebabkan pembelajaran menjadi bermakna, yang relevan dengan teori belajar bermakna Ausubel. Kegiatan pembelajaran perlu ditingkatkan adanya kemampuan literasi sains agar peserta didik ahli dalam menghubungkan proses yang sedang terjadi dengan konsep-konsep yang ada sehingga dapat mengaplikasikannya di kehidupan sehari-hari [10].

Kegiatan laboratorium dapat memicu keterlibatan aktif peserta didik selama proses pembelajaran. Peserta didik dituntut untuk mengumpulkan, menafsirkan data dengan menyajikan hasil yang diperoleh, dan menganalisis data. Analisis data yang berupa beberapa pertanyaan digunakan untuk menjawab pertanyaan ilmiah yang nantinya akan dapat ditarik sebuah kesimpulan [25]. Serangkaian kegiatan tersebut dapat meningkatkan kemampuan literasi sains peserta didik yang merupakan bagian dari domain literasi sains yaitu domain kompetensi.

\section{SIMPULAN}

Berdasarkan hasil analisis dan pembahasan tentang penelitian pengembangan ini dinyatakan layak dilihat dari aspek validitas, kepraktisan, dan keefektifan dapat disimpulkan bahwa:

1. Validitas LKPD berwawasan green chemistry untuk meningkatkan kemampuan literasi sains pada materi larutan elektrolit dan non elektrolit dinyatakan valid atas validitas isi dan validitas konstruk berturut-turut diperoleh persentase sebesar $79,75 \%$ berada dalam kriteria valid dan $82,84 \%$ yang berada pada kriteria sangat valid.

2. Kepraktisan dari LKPD yang dikembangkan dinyatakan praktis ditinjau dari observasi aktivitas dan angket respon peserta didik yang mendapatkan persentase rata-rata sebesar 93,05\% dan 94,79\% yang berada pada kriteria praktis sekali.
3. Keefektifan LKPD dikatakan efektif ditinjau dari hasil pretest serta posttest kemampuan literasi sains yang menunjukkan peningkatan pada peserta didik disertai dengan nilai dari $\mathrm{N}$ Gain yang didapatkan sebesar 0,84 dengan kategori yang tinggi.

\section{SARAN}

Berdasarkan dari penelitian pengembangan LKPD yang telah dilakukan, terdapat beberapa saran yang diberikan terhadap penelitian selanjutnya:

1. Prinsip-prinsip green chemistry yang diterapkan tidak hanya yang sudah diterapkan oleh peneliti, melainkan dapat menerapkan prinsip yang lain.

2. Materi yang dapat diterapkan prinsip-prinsip green chemistry tidak hanya larutan elektrolit dan non elektrolit saja, melainkan dapat menggunakan materi lainnya.

\section{DAFTAR PUSTAKA}

1. BSNP. 2006. Standar Isi Untuk Satuan Pendidikan Dasar dan Menengah. Jakarta: Badan Standar Nasional Pendidikan.

2. Ariningtyas, A., Wardani, S., \& Mahatmanti, W. 2017. Efektivitas Lembar Kerja Siswa Bermuatan Etnosains Materi Hidrolisis Garam untuk Meningkatkan Literasi Sains Siswa SMA. Journal of Innovative Science Education, Vol. 2, No. 2, Hal 186-196.

3. Hidayatin, S., \& Mitarlis. 2018. Pengembangan Lembar Kegiatan Peserta Didik (LKPD) pada Materi Koloid untuk Melatihkan Keterampilan Literasi Sains. Unesa Journal of Chemical Education, Vol. 7, No. 1, Hal 76-80.

4. Kemendikbud. 2016. Permendikbud No.20 Tahun 2016 Tentang Standar Kompetensi Lulusan Pendidikan Dasar dan Menengah. Jakarta: Mendikbud.

5. Prastowo, A. 2011. Panduan Kreatif Membuat Bahan Ajar Inovatif: Menciptakan Metode Pembelajaran yang Menarik dan Menyenangkan. Yogyakarta: Diva Press. 
6. Depdiknas. 2008. Panduan Pengembangan Bahan Ajar. Jakarta: Depdiknas.

7. OECD. 2016. Result in Focus PISA 2015: Draft Science Framework. Paris: OECD Publishing.

8. Riyadhin, A. I. F., \& Mitarlis. 2018. Pengembangan Lembar Kegiatan Siswa (LKS) untuk Melatihkan Kemampuan Literasi Sains Siswa pada Materi Redoks. Unesa Journal of Chemical Education, Vol. 1, No. 1, Hal 8-13.

9. Siregar, E. \& Nara, H. 2014. Teori Belajar dan Pembelajaran. Bogor: Ghalia Indonesia.

10. Wardani, D. A., \& Mitarlis. 2018. Pengembangan Lembar kerja peserta didik untuk Meningkatkan Keterampilan Literasi Sains pada Materi Hidrokarbon dan Minyak Bumi. UNESA Journal of Chemical Education, Vol. 7, No. 2, Hal 123-128.

11. Lin, Y., Zhao, H., Yu, F., \& Yang, J. 2018. Design of an Extended Experiment with Electrical Double Layer Capacitors: Electrochemical Energy Storage Devices in Green Chemistry. Journal MDPI Sustainability, Vol. 10, Hal 3630.

12. Marco, B. A. de., Rechelo, B. S., Totoli, E. G., Kogawa, A. C. 2019. Evolution of Green Chemistry and Its Multidimensional Impacts. Saudi Pharmaceutical Journal, 27, Hal 1-8.

13. Manahan. 2006. Chemistry, green chemistry, and environmental chemistry. From green chemistry and the Ten Commandments of Sustainability, ChemChar Research, Inc., 2006 mahanans@missouri.edu

14. Mitarlis, Ibnu, S., Rahayu, S., \& Sutrisno. 2017. Environmental Literacy with Green Chemistry Oriented in $21^{\text {st }}$ Century Learning. AIP Conference Proceedings, 1911, 020020-1 - 020020-6.

15. Aisyah \& Dwiningsih, K. (2017). Pengembangan Lembar Kegiatan Siswa
(LKS) Berorientasi Literasi Sains pada Materi Larutan Elektrolit dan Nonelektrolit. UNESA Journal of Chemical Education, Vol. 6, No. 2, Hal 329-333.

16. Yusmaita, E., Mudzakir, A., \& Hernani. 2017. Pengembangan Model Rekonstruksi pada Bahan Ajar Sel Elektrokimia Berbasis Green Chemistry. Jurnal Eksakta Pendidikan, Vol. 1, No. 1, Hal 71-78.

17. Ibrahim dan Wahyusukartingsih. 2014. Model Pembelajaran Inovatif Melalui Pemaknaan. Surabaya: Unesa University Press.

18. Riduwan. 2016. Skala Pengukuran VaribelVariabel Penelitian. Bandung: Alfabet.

19. Hake, R. R. 1998. Interactive Engagement Versus Traditional Methods: A Six Thousand Student Survey of Mechanics Test Data for Introductory Physics Courses. American Journal Physics, Vol. 66, No. 1, Hal 64-74.

20. Nursalim, M., Satiningsih, Hariastuti, R. T., Savira, S. I., \& Budiani, M. S. 2007. Psikologi Pendidikan. Surabaya: Unesa University Press.

21. Plomp, Tjeerd \& Nieveen, Nienke. 2010. An Introducing to Educational Design Research. Enschede, The Netherlands: Netherlands Institute for Curriculum Development.

22. Dahar, R. Wills. 2011. Teori-teori Belajar dan Pembelajaran. Jakarta: Erlangga.

23. Slavin, R. E. 2011. Psikologi Pendidikan. Jakarta: PT Indeks.

24. Fauziah, N., Andayani, Y., \& Hakim, A. 2019. Meningkatkan Literasi Sains Peserta Didik melalui Pembelajaran Berbasis Masalah Berorientasi Green Chemistry pada Materi Laju Reaksi. Jurnal Pijar MIPA, Vol. 14, No. 2, Hal 31-35.

25. Dichev, C., \& Dicheva, D. 2017. Towards Data Science Literacy. ScienceDirect Procedia Computer Science, Hal 2151-2160. 